Al-Ishlah: Jurnal Pendidikan - ISSN: 2087-9490 (p); 2597-940X (e)

Vol. 11, No. 1 (2019)

\title{
PENGARUH PENERAPAN GUESSING GAME TERHADAP KEMAMPUAN BERBICARA MAHASISWA STAIN BENGKALIS
}

\author{
Kurniati \\ STAIN Bengkalis \\ Email: Kurniati_kurniati@gmail.com \\ Ervina \\ STAIN Bengkalis \\ Email: ervina.evi@gmail.com
}

\begin{abstract}
Abstrak
This study aims to determine the students' speaking skill before and after applying Guessing Game and find out the effect of Guessing Game on the students' speaking skill at the first semester of English education study program of STAIN Bengkalis. This research is experimental research that involved 18 students at the first semester of English Education Study Program of STAIN Bengkalis. Speaking test was implemented in order to collect the students' speaking performance, and the collected data were quantitatively analyzed. Guessing Game has a less significant effect in improving the students' speaking skill at the first semester of English education study program of STAIN Bengkalis. This is evidenced by the results of $t$-o $(1,3)$ smaller than $t$-table.
\end{abstract}

Penelitian ini bertujuan untuk mengetahui kemampuan berbicara mahasiswa sebelum dan sesudah menggunakan guessing game dan mengetahui pengaruh penerapan guessing game terhadap keterampilan berbicara mahasiswa semester pertama program studi Tadris Bahasa Inggris, STAIN, Bengkalis. Penelitian ini adalah penelitian eksperimen. Peserta penelitian adalah 18 orang mahasiswa semester satu program studi Tadris Bahasa Inggri,s STAIN, Bengkalis. Insrtumen yang digunakan dalam mengumpulkan data adalah wawancara. Data dianalisis secara kuantitatif. Temuan menunjukkan bahwa bahwa nilai berbicara mahasiswa sebelum penelitian masih rendah. Ini dibuktikan dengan nilai rata-rata speaking mahasiswa sebelum dilakukan penelitian adalah 2,98 (59,57). Sementara, nilai speaking mahasiswa setelah dilakukan penelitian sudah di atas rata-rata nilai kelulusan. Hal ini dibuktikan dengan nilai rata-rata speaking mahasiswa setelah dilakukan penelitian adalah 3,38 (67,70). Namun, guessing game memberikan pengaruh yang kurang signifikan terhadap peningkatan kemampuan berbicara mahasiswa, ini dibuktikan dengan hasil $t_{0}(1,3)$ lebih kecil dari $t_{\text {table. }}$.

Kata Kunci: Guessing Game, Kemampuan Berbicara 
Al-Ishlah: Jurnal Pendidikan - ISSN: 2087-949o (p); 2597-940X (e)

Vol. 11, No. 1 (2019)

\section{PENDAHULUAN}

Berbicara adalah salah satu keterampilan dalam belajar bahasa. Artinya, semua pelajar bahasa Inggris diharapkan bisa berbahasa Inggris dan menyampaikan pendapatnya, baik lisan maupun tulisan, dalam Bahasa Inggris. Berbicara dan menulis dianggap sebagai keterampilan produktif, dalam hal lain mendengarkan dan membaca dianggap keterampilan.

Berbagai definisi berbicara dinyatakan oleh beberapa ahli. Menurut Harmer (2001: 16), berbicara adalah keterampilan yang melibatkan beberapa jenis organ bicara dari pengguna bahasa. Selain itu, Long dan Jack (1987: 189) menyatakan bahwa berbicara adalah serangkaian kemampuan yang kompleks yang melibatkan banyak komponen; termasuk pengucapan, pendengaran, dan keterampilan tata bahasa. Dapat disimpulkan bahwa berbicara adalah kemampuan menghasilkan bahasa secara lisan yang terdiri atas komponen lain untuk menghasilkan bahasa lisan yang baik.

Keterampilan berbicara adalah kemampuan yang berfungsi untuk mengekspresikan gagasan, perasaan, pikiran, dan kebutuhan secara lisan (Hornby, 1995: 826). Tujuan utama pengajaran keterampilan berbicara adalah kefasihan mulut; kemampuan untuk mengekspresikan diri secara jelas; wajar, akurat, dan tanpa keraguan yang tidak semestinya (Byrne, 1984: 9). Singkatnya, kemampuan berbicara adalah kemampuan yang kompleks untuk menggunakan bahasa dalam mengekspresikan diri dengan suara biasa.

Dari beberapa teori tentang kemampuan berbicara, dapat disimpulkan bahwa berbicara adalah salah satu keterampilan produktif, yaitu kemampuan dalam menggunakan bahasa secara lisan melalui suara untuk menyajikan informasi dan menghasilkan gagasan. Keterampilan berbicara adalah seperangkat kemampuan untuk mengekspresikan gagasan, perasaan, atau pemikiran secara jelas, cukup, dan akurat. Mengekspresikan ide untuk berinteraksi dengan anggota masyarakat lain melibatkan banyak komponen, termasuk pengucapan, pendengaran, dan keterampilan tata bahasa, baik secara verbal maupun nonverbal, dari berbagai konteks. Untuk berbicara dengan baik, mahasiswa perlu mempraktikkan bahasa Inggris mereka. Banyak usaha yang bisa dilakukan untuk meningkatkan kemampuan berbicara mereka, seperti melakukan dialog, bermain, presentasi lisan, diskusi kelompok kecil, debat, dan melakukan permainan. Kegiatan tersebut tidak hanya meningkatkan kemampuan berbicara, tetapi juga membantu mereka untuk aktif menggunakan bahasa Inggris.

Tujuan utama dalam berbicara adalah berkomunikasi. Ini sesuai dengan teori yang mengatakan bahwa keterampilan berbicara adalah kemampuan yang berfungsi untuk mengekspresikan gagasan, perasaan, pikiran, dan kebutuhan secara lisan (Hornby, 1995: 826). 
Al-Ishlah: Jurnal Pendidikan - ISSN: 2087-949o (p); 2597-940X (e)

Vol. 11, No. 1 (2019)

Peneliti menemukan bahwa mahasiswa memiliki masalah dalam berbicara bahasa Inggris, bahkan Peneliti telah melakukan beberapa upaya untuk memperbaiki kemampuan berbicara mereka. Peneliti mengamati 18 mahasiswa pada semester pertama Program Studi Tadris Bahasa Inggris, STAIN, Bengkalis, dan menemukan bahwa mahasiswa yang berbicara dengan menggunakan bahasa Inggris di kelas sangat sedikit.

Selanjutnya, Peneliti mewawancarai beberapa mahasiswa untuk mengetahui masalah mereka dalam berbicara. Berdasarkan hasil wawancara tersebut, peneliti menemukan ada beberapa faktor yang mempengaruhi ketidakaktifan mahasiswa dalam menggunakan bahasa Inggris secara lisan, di antaranya adalah mereka tidak bisa mengekspresikan ide karena kurangnya kosakata. Faktor awalnya terkait kemampuan mahasiswa untuk mengekspresikan ide. Diketahui bahwa berbicara adalah keterampilan yang kompleks yang membutuhkan kosakata. Kosakata biasanya digunakan oleh mahasiswa sebagai salah satu alasan untuk tidak berbicara dalam bahasa Inggris. Mahasiswa mengemukakan bahwa mereka kesulitan megungkapkan gagasan karena minimnya penguasaan kata-kata dalam bahasa Inggris dan juga mengalami kesulitan dalam menggunakan kosakata baru dalam membangun sebuah kalimat. Alasan lainnya adalah bahwa mereka takut menggunakan kata-kata yang salah atau tidak pantas dalam berbicara; mereka lupa atau tidak mampu mengemukakan kata-kata yang ingin mereka katakan; mereka selalu memikirkan tentang tata bahasa (grammatical) ketika akan berbicara. Singkatnya, salah satu masalah mahasiswa dalam berbicara terkait dengan penerapan kosakata. Mereka terlalu khawatir tentang memilih kosakata yang tepat dan menyusun setiap kata menjadi kalimat yang benar secara grammatikal.

Masalah selanjutnya, mahasiswa tidak percaya diri untuk berbicara dalam bahasa Inggris. Kepercayaan untuk berbicara juga merupakan faktor penting bagi mahasiswa karena memberikan kontribusi besar bagi prestasi pelajar dalam menguasai bahasa. Di sisi lain, seorang mahasiswa yang memiliki kepercayaan diri dan tidak gugup akan memotivasi mahasiswa lainnya untuk mempraktikkan bahasa dengan baik sehingga mereka akan menyadari keuntungan menjadi percaya diri dalam belajar bahasa Inggris. Beberapa mahasiswa ingin mengatakan sesuatu. tetapi mereka tidak cukup percaya diri untuk mengungkapkannya dalam bahasa Inggris. Singkatnya, kepercayaan diri merupakan indikator penting untuk mendukung keterampilan mahasiswa dalam menggunakan bahasa Inggris secara lisan. Selanjutnya, aktivitas kelas tidak mendukung mereka untuk berbicara bahasa Inggris. Kondisi belajar mengajar juga merupakan aspek lain yang dapat mempengaruhi kemampuan mahasiswa untuk menggunakan bahasa Inggris dalam kehidupan sehari-hari mereka. Situasi yang menarik di kelas juga merupakan salah satu hal yang sangat dibutuhkan oleh mahasiswa dalam belajar bahasa, 
Al-Ishlah: Jurnal Pendidikan - ISSN: 2087-949o (p); 2597-940X (e)

Vol. 11, No. 1 (2019)

terutama untuk meningkatkan minat mereka dalam menghasilkan bahasa secara lisan. Seorang pengajar bahasa Inggris seharusnya mampu menampilkan beragam aktivitas yang dapat menstimulus peserta didik untuk berbicara menggunakan bahasa Inggris, seperti menerapkan permainan-permainan komunikatif, salah satunya adalah guessing game yang diterapkan oleh peneliti dalam penelitian ini.

Ada banyak alasan untuk menggunakan game dalam pembelajaran berbicara. Permainan memberi kesempatan kepada mahasiswa untuk menggunakan bahasa Inggris secara lisan. Ini berarti bahwa mahasiswa dapat berlatih dan mengembangkan kemampuan mereka untuk berbicara bahasa Inggris. Game juga memberikan kesenangan dan kesantaian sambil tetap semangat dalam belajar bahasa. Diharapkan bagi pelajar yang pemalu atau lamban dapat menjadi peserta aktif yang bias menunjukkan kemampuan dan menemukan kepercayaan diri mereka untuk berkomunikasi dalam bahasa asing. Di antara banyak teknik permainan dalam pembelajaran berbicara, guessing game bisa diaplikasikan.

Guessing game adalah permainan yang objeknya adalah menebak beberapa jenis informasi, seperti sebuah kata, frasa, judul, atau lokasi objek. Guessing game adalah strategi yang dikembangkan oleh beberapa ahli.

Menurut Klippel (1994: 13), aturan dasar permainan menebak sangat sederhana. Satu orang tahu sesuatu yang ingin diketahui oleh orang lain. Sementara, Wright dan Buck (1998: 169) mengatakan bahwa pada dasarnya, dalam menebak dan bermain harus berspekulasi, ada yang tahu sesuatu dan yang lain harus mencari tahu apa itu. Selain itu, Webster (1986: 1008) menjelaskan bahwa guessing game adalah permainan yang para pesertanya bersaing secara individu atau tim dalam mengidentifikasi sesuatu.

Berdasarkan definisi tersebut, dapat disimpulkan bahwa guessing game adalah permainan dengan seseorang atau peserta mengetahui sesuatu dan bersaing secara individu atau dalam tim untuk mengidentifikasi ataumenebaknya. Ada banyak konsep menebak game yang bisa diaplikasikan dalam pembelajaran berbicara.

Yang pasti, pentingnya guessing game adalah memberikan latihan dalam berkomunikasi. Bisa dikatakan bahwa guessing game memberi motivasi kepada mahasiswa agar tidak merasa bosan selama proses belajar. Meskipun begitu, yang terpenting adalah memberikan kesempatan pada mahasiswa berlatih bahasa Inggris. Beberapa bentuk permainan adalah "menebak apa itu" atau "tebak di mana itu" . Bentuk permainan ini bisa digunakan dalam mengajar tentang profesi, hewan, atau orang-orang dalam kelompok usia yang berbeda (bayi, anak, remaja, dewasa muda, orang lanjut usia). Pernyataan tersebut mengatakan bahwa dengan memberi beberapa konsep guessing game seperti "tebak apa itu" atau "tebak di mana tempatnya". Jadi, dapat disimpulkan bahwa guessing game memberikan mahasiswa lebih banyak kesempatan dalam merumuskan pertanyaan. 
Al-Ishlah: Jurnal Pendidikan - ISSN: 2087-949o (p); 2597-940X (e)

Vol. 11, No. 1 (2019)

Selain itu, guessing game adalah situasi komunikatif sejati dan sangat penting untuk latihan bahasa asing dengan kesenangan dan kegembiraan yang tidak hanya dapat diterapkan bagi mahasiswa program studi Bahasa Inggris, tetapi juga untuk mahasiswa program studi lainnya. Pastinya, ini dapat membangkitkan minat dan mendorong mahasiswa untuk berkomunikasi karena kombinasi antara bahasa dan praktik yang menyenangkan.

Menurut Harmer (2007: 238), prosedur guessing game adalah sebagai berikut.

1. Siswa dibagi dalam tim kecil;

2. Pada setiap tim, satu anggota duduk membelakangi papan tulis;

3. Guru menulis kata atau frasa di papan tulis;

4. Semua kelompok yang dapat melihat kata atau frasa ini harus menjelaskan (tanpa mengucapkan kata atau frasa itu sendiri) kepada anggota tim yang duduk yang membelakangi papan tulis;

5. Jika siswa yang membelakangi papan tulis dapat menebak kata atau fras, tim tersebut akan mendapat poin .

Nation and Newton (2009: 30-32) menjelaskan bahwa guessing game terdiri atas beberapa langkah sebagai berikut. Pertama, mahasiswa dibagi menjadi beberapa kelompok, satu kelompok terdiri atas 4 atau 5 orang mahasiswa. Kedua, satu kelompok diminta untuk tampil di depan kelas dan salah satu anggota kelompok memilih kategori yang akan dimainkan dari sebuah kotak. Ketiga, salah satu anggota kelompok duduk membelakangi kata/gambar yang ditunjukkan dan mencoba menebak kata/gambar yang dimaksud dan bertanya terlebih dahulu tentang kategori, apakah ini kata untuk makanan, untuk furnitur, atau untuk transportasi? Sementara, keempat mahasiswa yang lain hanya menjawab "ya" atau "tidak", sampai kategori dan kata yang tepat telah ditebak. Keempat, setelah kata/gambar bisa ditebak, dilanjutkan dengan anggota kelompok lainnya bergantian duduk di depan dan menebak kata berikutnya.

Banyak ahli menjelaskan prosedur guessing game secara berbeda. Peneliti memutuskan untuk menggunakan teori Harmer (2007) karena prosedur yang dijelaskan sangat sederhana dan mudah untuk dipahami dan diterapkan. Jadi, untuk mengatasi permasalahan yang dihadapi mahasiswa semester satu Program Studi Tadris, Bahasa Inggris, STAIN, Bengkalis, peneliti memutuskan untuk menerapkan guessing game selama kegiatan belajar mengajar, terutama dalam mengajar berbicara. Artinya, peneliti akan berusaha menciptakan situasi yang membuat mahasiswa harus bekerja sama dengan pasangannya untuk mengembangkan kemampuan berbicara sehingga nantinya diharapkan mampu merangsang mereka untuk berbicara dan mengembangkan gagasan dalam berbicara. 
Al-Ishlah: Jurnal Pendidikan - ISSN: 2087-949o (p); 2597-940X (e)

Vol. 11, No. 1 (2019)

\section{METODE PENELITIAN}

Penelitiaan ini dilakukan untuk mengetahui kemampuan berbicara mahasiswa sebelum dan sesudah menggunakan guessing game dan juga untuk mengetahui adanya pengaruh yang signifikan dari penerapan guessing game dalam kemampuan berbicara mahasiswa pada semester pertama Program Studi Tadris, Bahasa Inggris, STAIN, Bengkalis.

Jenis penelitian ini adalah penelitian quasi experimental dengan one group pretest posttest design. Penelitian ini tidak menggunakan kelas pembanding, tetapi sudah menggunakan tes awal sehingga besarnya efek atau pengaruh dapat diketahui secara pasti. Sementara, subjek penelitian ini adalah mahasiswa 18 orang mahasiswa yang terdiri atas 17 orang perempuan dan 1 orang laki-laki. Penelitian ini dilakukan mulai bulan September sampai November 2018.

Selanjutnya, tes digunakan untuk mengumpulkan data tentang kemampuan berbicara mahasiswa. Untuk memastikan keabsahan tes, tes dilakukan berdasarkan silabus semester pertama Program Studi Tadris Bahasa Inggris dengan contoh meminta dan memberikan pendapat dan menunjukkan apresiasi. Dari silabus, peneliti menggunakan bahan berbicara tentang komunikasi umum untuk semester pertama dan menyusunnya ke dalam rencana pelajaran dan membuat instrumen yang dapat mengukur kemampuan berbicara mahasiswa. Untuk mendapatkan skor kemampuan berbicara siswa, Peneliti menggunakan rubrik penilaian analitik yang diadaptasi dari Hughes (2005: 131-132). Peneliti akan melihat kriteria berbicara, aksen, tata bahasa, kosakata, kelancaran, dan pemahaman. Sementara, data dianalisis secara kuantitatif dan kualitatif.

\section{HASIL DAN PEMBAHASAN}

Berdasarkan data yang diperoleh dari tes yang diberikan kepada mahasiswa sebelum penelitian dilakukan, dapat disimpulkan bahwa sebagian besar mahasiswa memiliki nilai berbicara yang rendah. Hal ini menunjukkan bahwa kemampuan berbicara mahasiswa sebelum dilakukan penelitian tidak seperti yang diharapkan. Hasil tes yang diberikan sebelum pelaksanaan penelitian dapat dilihat pada tabel berikut. 
Al-Ishlah: Jurnal Pendidikan - ISSN: 2087-949o (p); 2597-940X (e)

Vol. 11, No. 1 (2019)

Tabel 1. Nilai berbicara mahasiswa sebelum dilakukan penelitian

\begin{tabular}{|c|c|c|c|c|}
\hline Mahasiswa & Nilai Total & $\begin{array}{c}\text { Nilai Rata- } \\
\text { Rata }\end{array}$ & Nilai & Ket. \\
\hline S1 & 17,98 & 3,59 & 71,92 & Pass \\
\hline S2 & 13,65 & 2,73 & 54,6 & Fail \\
\hline S3 & 15,66 & 3,13 & 62,64 & Pass \\
\hline S4 & 12,97 & 2,59 & 51,88 & Fail \\
\hline S5 & 18,32 & 3,66 & 73,28 & Pass \\
\hline S6 & 13,3 & 2,66 & 53,2 & Fail \\
\hline S7 & 17,98 & 3,59 & 71,92 & Pass \\
\hline S8 & 12,65 & 2,53 & 50,6 & Fail \\
\hline S9 & 12,98 & 2,59 & 51,92 & Fail \\
\hline S10 & 14,99 & 2,99 & 59,96 & Fail \\
\hline S11 & 15,33 & 3,06 & 61,32 & Pass \\
\hline S12 & 17,99 & 3,59 & 71,96 & Pass \\
\hline S13 & 16,65 & 3,33 & 66,6 & Pass \\
\hline S14 & 12,31 & 2,46 & 49,24 & Fail \\
\hline S15 & 13,31 & 2,66 & 53,24 & Fail \\
\hline S16 & 15,99 & 3,19 & 63,96 & Pass \\
\hline S17 & 13,99 & 2,79 & 55,96 & Fail \\
\hline S18 & 11,98 & 2,39 & 47,92 & Fail \\
\hline Total & 268,03 & 53,606 & 1072,12 & \\
\hline Mean & 14,89 & 2,98 & 59.57 & \\
\hline
\end{tabular}

Pada tabel. 1 dinyatakan bahwa nilai rata-rata mahasiswa adalah 2,98 $(59,57)$, ada $8(45 \%)$ mahasiswa yang dapat mencapai nilai minimum (60) dan ada $10(55 \%)$ mahasiswa yang mendapat nilai di bawah nilai minimum $(\leq 60)$ atau gagal dalam tes berbicara. Sementara itu, data yang diperoleh dari tes yang diberikan kepada mahasiswa setelah penelitian dilakukan dapat disimpulkan bahwa sebagian besar mahasiswa lulus dalam tes berbicara. Selanjutnya, nilai berbicara mahasiswa yang diperoleh melalui tes yang diberikan setelah penelitian dilakukan sebagaimana dijelaskan dalam tabel berikut. 
Al-Ishlah: Jurnal Pendidikan - ISSN: 2087-949o (p); 2597-940X (e)

Vol. 11, No. 1 (2019)

Tabel 2. Nilai berbicara mahasiswa setelah dilakukan penelitian

\begin{tabular}{|c|c|c|c|c|}
\hline Mahasiswa & Nilaitotal & $\begin{array}{c}\text { Nilai Rat- } \\
\text { Rata }\end{array}$ & Nilai & Ket. \\
\hline S1 & 20 & 4 & 80 & Pass \\
\hline S2 & 13,3 & 2,66 & 53,2 & Fail \\
\hline S3 & 17,31 & 3,46 & 69,24 & Pass \\
\hline S4 & 16,98 & 3,39 & 67,92 & Pass \\
\hline S5 & 18,64 & 3,72 & 74,56 & Pass \\
\hline S6 & 15,32 & 3,06 & 61,28 & Pass \\
\hline S7 & 19,32 & 3,86 & 77,28 & Pass \\
\hline S8 & 13,64 & 2,72 & 54,56 & Fail \\
\hline S9 & 16,98 & 3,39 & 67,92 & Pass \\
\hline S10 & 18,31 & 3,66 & 73,24 & Pass \\
\hline S11 & 18,98 & 3,79 & 75,92 & Pass \\
\hline S12 & 19,66 & 3,93 & 78,64 & Pass \\
\hline S13 & 18,64 & 3,72 & 74,56 & Pass \\
\hline S14 & 15,00 & 3,00 & 60,0 & Pass \\
\hline S15 & 15,65 & 3,13 & 62,6 & Pass \\
\hline S16 & 17,65 & 3,53 & 70,6 & Pass \\
\hline S17 & 16,31 & 3,26 & 65,24 & Pass \\
\hline S18 & 12,97 & 2,59 & 51,88 & Fail \\
\hline Total & 304,65 & 60,87 & 1218,64 & \\
\hline Mean & 16,93 & 3,38 & 67,70 & \\
\hline & & & & \\
\hline
\end{tabular}

Dari hasil tes berbicara pada tabel. 2 dinyatakan bahwa nilai rata-rata mahasiswa adalah 3,38 (67,70) dalam kategori baik. Ada $3(16,7 \%)$ dari $18(83,3)$ siswa yang tidak dapat mencapai nilai kelulusan. Pada tabel di atas juga ditunjukkan bahwa angka kelulusan sangat signifikan dari jumlah total siswa di kelas dibandingkan dengan hasil tes sebelum penelitian. Nilai sebelum dan sesudah treatment dijelaskan pada tabel berikut. 
Al-Ishlah: Jurnal Pendidikan - ISSN: 2087-949o (p); 2597-940X (e)

Vol. 11, No. 1 (2019)

Tabel 3. Nilai speaking mahsiswa sebelum dan sesudah penelitian

\begin{tabular}{|c|c|c|c|c|c|}
\hline No & Students & $\begin{array}{c}\text { Nilai } \\
\text { Pre-test } \\
(\mathbf{X})\end{array}$ & $\begin{array}{c}\text { Nilai } \\
\text { Post-test } \\
(\mathbf{Y})\end{array}$ & $\mathbf{D}=(\mathbf{X}-\mathbf{Y})$ & $\mathbf{D}^{2}=(\mathbf{X}-\mathbf{Y})^{\mathbf{2}}$ \\
\hline 1 & Student 1 & 72 & 80 & -8 & 64 \\
\hline 2 & Student 2 & 55 & 53 & 2 & 4 \\
\hline 3 & Student 3 & 63 & 69 & -6 & 36 \\
\hline 4 & Student 4 & 52 & 68 & -16 & 256 \\
\hline 5 & Student 5 & 73 & 75 & -2 & 4 \\
\hline 6 & Student 6 & 53 & 61 & -8 & 64 \\
\hline 7 & Student 7 & 72 & 77 & -5 & 25 \\
\hline 8 & Student 8 & 51 & 55 & -4 & 14 \\
\hline 9 & Student 9 & 52 & 68 & -16 & 256 \\
\hline 10 & Student 10 & 59 & 73 & -14 & 196 \\
\hline 11 & Student 11 & 61 & 76 & -15 & 225 \\
\hline 12 & Student 12 & 72 & 79 & -7 & 49 \\
\hline 13 & Student 13 & 67 & 75 & -8 & 64 \\
\hline 14 & Student 14 & 49 & 60 & -11 & 121 \\
\hline 15 & Student 15 & 53 & 63 & -10 & 100 \\
\hline 16 & Student 16 & 64 & 71 & -7 & 49 \\
\hline 17 & Student 17 & 56 & 65 & -9 & 81 \\
\hline 18 & Student 18 & 48 & 52 & -4 & 16 \\
\hline & Total & $\sum \mathrm{X}=$ & $\sum \mathrm{Y}=1220$ & $\sum \mathrm{D}=-152$ & $\sum \mathrm{D}^{2}=23104$ \\
\hline & & 1072 & & & \\
\hline
\end{tabular}

Berdasarkan tabel.3 di atas dijelaskan bahwa total nilai pretes mahasiswa adalah 1072, total nilai postes mahasiswa adalah 1220. Selanjutnya, untuk menemukan nilai akhir dan mengetahui pengaruh guessing game terhadap kemampuan berbicara bahasa Inggris, data akan dianalisis menggunakan rumus berikut.

Untuk mencari nilai tengah dari standard perbedaan :

$$
\begin{aligned}
M_{D} & =\frac{\sum \mathrm{D}}{N} \\
& =\frac{-152}{18} \\
=-8,44 &
\end{aligned}
$$


Al-Ishlah: Jurnal Pendidikan - ISSN: 2087-949o (p); 2597-940X (e)

Vol. 11, No. 1 (2019)

Untuk mencari standar deviasi

$$
\begin{aligned}
S D_{D} & =\sqrt{\frac{\sum_{D} 2}{N}-\left[\frac{\sum_{D}}{N}\right]^{2}} \\
& =\sqrt{\frac{23104}{18}-\left[\frac{-152}{18}\right]^{2}} \\
& =\sqrt{1283,56}-[-8,44] \\
& =27,39
\end{aligned}
$$

Untuk mencari standard error

$$
\begin{aligned}
S E_{M D} & =\frac{S D_{D}}{\sqrt{\mathrm{N}-1}} \\
& =\frac{27,39}{\sqrt{18-1}} \\
& =\frac{27,39}{4,13} \\
& =6,64
\end{aligned}
$$

Untuk mencari nilai akhir

$$
\begin{gathered}
\mathbf{t}_{\mathbf{0}}=\frac{M_{D}}{S E_{M D}} \\
=\frac{-8,44}{6,64} \\
=1,27
\end{gathered}
$$

Untuk menemukan $\mathrm{db}=\mathrm{N}-1=18-1=17$

Dari $\mathrm{db}=17$, t-tabel signifikansi $5 \%$ adalah 1,74 dan $1 \%$ adalah 1,3 dengan membandingkan " $\mathrm{t}$ " dalam $\mathrm{t} 0=1,27$ dan skor " $\mathrm{t}$ " di t-tabel 5\% 1,74 dan $\mathrm{t}$ tabel $1 \%=1,3$ dapat disimpulkan $\mathrm{t}_{0}$ lebih rendah yaitu $\mathrm{tt}-1,3>1,27<1,74$

Tabel 4. Nilai "t $t$ " pada level signifikan

\begin{tabular}{|c|c|c|c|}
\hline \multirow{2}{*}{ Df or db } & \multicolumn{2}{|c|}{ The critical of " $\mathbf{t}$ " in significant level } & \multirow{2}{*}{$\mathbf{t}_{\mathbf{0}}$} \\
\cline { 2 - 3 } & $5 \%$ & $1 \%$ & 1,27 \\
\hline 17 & 1,74 & 1,3 & \multirow{2}{*}{} \\
\hline
\end{tabular}

Dari hasil di atas dapat disimpulkan bahwa guessing game kurang memberikan pengaruh yang signifikan terhadap kemampuan berbicara mahasiswa semester pertama Program Studi Tadris Bahasa Inggris, STAIN, Bengkalis. Berdasarkan analisis peneliti, terkait dengan rendahnya pengaruh penggunaan guessing game terhadap keterampilan mahasiswa dalam menggunakan bahasa Inggris secara lisan terdapat faktor lain yang mempengaruhi, seperti bahan ajar, media, teknik pengajaran, dan guru yang kreatif. 
Al-Ishlah: Jurnal Pendidikan - ISSN: 2087-949o (p); 2597-940X (e)

Vol. 11, No. 1 (2019)

Berdasarkan temuan pada penelitian, didapatkan nilai rata-rata yang paling tinggi dari lima komponen berbicara adalah kosakata, sedangkan nilai yang paling rendah adalah kelancaran. Penggunaan guessing game dalam keterampilan berbicara mahasiswa memberikan pengaruh yang kurang signifikan terhadap kemampuan berbicara mahasiswa. Hal ini bisa dilihat dari hasil tes sebelum dan setelah penelitian. Itu juga bisa dilihat dari aktivitas, minat, kepercayaan diri, dan keseriusan mahasiswa dalam proses belajar mengajar. Peningkatan ini disimpulkan melalui pengamatan yang dilakukan oleh peneliti.

Hughes dan Brown (2005: 131-132) mengatakan bahwa berbicara memiliki lima aspek, yaitu aksen, tata bahasa, kosakata, kelancaran, dan pemahaman. Di sisi lain, Harris (1980: 467) mengatakan bahwa guru biasanya tidak memiliki masalah untuk meningkatkan keterampilan siswa jika ia membuat praktik yang sesuai dalam mengajar dengan menerapkan teknik yang tepat. Dari hasil penelitian, dapat disimpulkan bahwa dalam penerapan guessing game, aspek berbicara seperti yang dikatakan Hugges dapat ditingkatkan. Itu artinya, keterampilan mahasiswa menggunakan bahasa Inggris secara lisan akan semakin baik.

\section{SIMPULAN}

Penelitian ini difokuskan pada penerapan guessing game dalam meningkatkan keterampilan berbicara mahasiswa. Berdasarkan hasil penelitian ini, dapat disimpulkan bahwa berdasarkan analisis data didapatkan nilai rata-rata berbicara mahasiswa sebelum dilakukan penelitian adalah 2,98 (59,57). Hal ini berarti nilai berbicara mahasiswa masih rendah. Berdasarkan nilai rata-rata berbicara mahasiswa setelah dilakukan penelitian adalah $3,38(67,70)$. Hal ini berarti rata-rata mahasiswa sudah mendapatkan nilai yang baik. Guessing game juga memberikan pengaruh yang kurang signifikan terhadap peningkatan kemampuan berbicara mahasiswa semester satu Program Studi Tadris Bahasa Inggris, STAIN, Bengkalis. Hal ini dibuktikan dengan hasil akhir bahwa $t_{0}(1,27)$

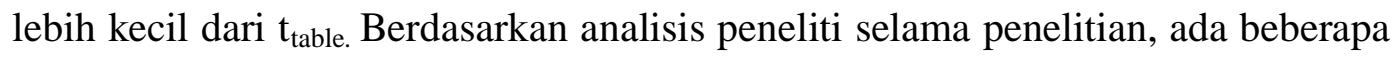
faktor lain yang mempengaruhi keterampilan mahasiswa dalam menggunakan bahasa Inggris secara lisan, yaitu bahan ajar, media pembelajaran, teknik pengajaran, dan guru yang kreatif.

\section{DAFTAR PUSTAKA}

Brown, H.Doughlas. (1994). Teaching by Principles: An intractive Approach to Language Pedagogy. New Jersey: Eaglewood Cliffs: Prentice Hall Regents. 
Al-Ishlah: Jurnal Pendidikan - ISSN: 2087-949o (p); 2597-940X (e)

Vol. 11, No. 1 (2019)

Byrne, D. (1984). Language learning in the Classroom: Teaching Oral English. Hong Kong: Longman.

Harmer, Jeremy. (2007). The Practice of English Language Teaching. Longman ELT; $4^{\text {th }}$ edition.

Hornby, A.S. (1995). Oxford Advanced Learner's Dictionary of Current Langaunge. Oxford: Oxford University Press.

Hughes, Arthur. (2005). Testing for Language Teachers. Cambridge: Cambridge University.

Klippel, Friederike. (1994). Keep Talking. Cambridge: Cambridge University Press.

Macher, Arnold Knopf. (2000). A simple card Guessing Game. Retrieved from http://www.combinatorics.org/Volume_8/PDF/v8i2r13.pdf on September $16,2018$.

Nation, I.S.P., and Newton, Jonathan. (2009). Teaching ESL/EFL Listening and S peaking. New York: Routledge Taylor\&Francis Group.

O’Malley, J.M, and LorraineV.P. (1996). Authentic Assesment for English Language learner .Virgine: Addison Wesley Publishing Company.

Qian, Tianying. (2005). On Contextual Guessing in Reading Comprehension.USChina Foreign Language Jul. 2005, Volume 3, No.7 (Serial No.22), ISSN1539-8080, USA.

Richard, Jack C. (2002). Curriculum Development in Language Teaching. Cambridge: Cambridge University Press.

Webster Merriem, (1986). Webster's Third New International Dictionary. Springfield, Merriem Webster inc. 